\title{
Focus on Mammalian Embryogenomics
}

\section{Genes involved in conceptus-endometrial interactions in ruminants: insights from reductionism and thoughts on holistic approaches}

\author{
Thomas E Spencer, Olivier Sandra ${ }^{1}$ and Eckhard Wolf ${ }^{2,3}$ \\ Department of Animal Science, Center for Animal Biotechnology and Genomics, Texas A\&M University, College \\ Station, Texas 77843, USA, ${ }^{1}$ Institut National de la Recherche Agronomique, UMR 1198 INRA-ENVA Biologie du \\ Développement et de la Reproduction, 78352 Jouy-en-Josas Cedex, France, ${ }^{2}$ Institute of Molecular Animal Breeding \\ and Biotechnology and ${ }^{3}$ Laboratory for Functional Genome Analysis (LAFUGA), Gene Center, Ludwig-Maximilians \\ University, Munich, Germany
}

Correspondence should be addressed to T E Spencer; Email: tspencer@tamu.edu

\begin{abstract}
This review summarizes new knowledge on expression of genes and provides insights into approaches for study of conceptus-endometrial interactions in ruminants with emphasis on the peri-implantation stage of pregnancy. Conceptus-endometrial interactions in ruminants are complex and involve carefully orchestrated temporal and spatial alterations in gene expression regulated by hormones from the ovary and conceptus. Progesterone is the hormone of pregnancy and acts on the uterus to stimulate blastocyst survival, growth, and development. Inadequate progesterone levels or a delayed rise in progesterone is associated with pregnancy loss. The mononuclear trophectoderm cells of the elongating blastocyst synthesize and secrete interferon- $\tau$ (IFNT), the pregnancy recognition signal. Trophoblast giant binucleate cells begin to differentiate and produce hormones including chorionic somatomammotropin 1 (CSH1 or placental lactogen). A number of genes, induced or stimulated by progesterone, IFNT, and/or CSH1 in a cell-specific manner, are implicated in trophectoderm adhesion to the endometrial luminal epithelium and regulation of conceptus growth and differentiation. Transcriptional profiling experiments are beginning to unravel the complex dynamics of conceptus-endometrial interactions in cattle and sheep. Future experiments should incorporate physiological models of pregnancy loss and be complemented by metabolomic studies of uterine lumen contents to more completely define factors required for blastocyst survival, growth, and implantation. Both reduction and holistic approaches will be important to understand the multifactorial phenomenon of recurrent pregnancy loss and provide a basis for new strategies to improve pregnancy outcome and reproductive efficiency in cattle and other domestic animals.
\end{abstract}

Reproduction (2008) 135 165-179

\section{Introduction}

The conceptus (embryo/fetus and associated extraembryonic membranes) and endometrium reciprocally interact throughout pregnancy. During the peri-implantation period, conceptus-endometrial interactions are influenced by progesterone and placental hormones required

This article was presented at the 2nd International Meeting on Mammalian Embryogenomics, 17-20 October 2007. The Co-operative Research Programme: Biological Resource Management for Sustainable Agricultural Systems of The Organisation for Economic Cooperation and Development (OECD) has supported the publication of this article. The meeting was also sponsored by Le conseil Régional Ilede-France, the Institut National de la Recherche Agronomique (INRA), Cogenics-Genome Express, Eurogentec, Proteigene, Sigma-Aldrich France and Diagenode sa. for establishment and maintenance of pregnancy. This review integrates established and new information on genes involved in conceptus-endometrial interactions with emphasis on knowledge generated from reductionist transcriptional profiling experiments conducted in cattle and sheep. The review also offers insights into holistic approaches using physiological models and systems biology for studying conceptus-endometrial interactions in ruminants. This area of reproductive biology is particularly important in ruminants due to relatively high levels of pregnancy loss during the peri-implantation period. In cattle, estimates indicate that fertilization rate is $90 \%$ with an average calving rate of about $55 \%$, suggesting an embryonic/fetal mortality of about $35 \%$; further, $70-80 \%$ of total embryonic loss occurs between days 8 and 16 after insemination (Diskin et al. 2006). Early 
pregnancy loss is even greater in the high-yielding dairy cattle, which is a major impediment to milk production efficiency (Moore \& Thatcher 2006).

\section{Overview of peri-implantation conceptus- endometrial interactions in ruminants}

Establishment of pregnancy in domestic ruminants (sheep, cattle, and goats) begins at the blastocyst stage and includes pregnancy recognition signaling, conceptus implantation, and placentation (for reviews, see Guillomot et al. 1993, Guillomot 1995, Spencer et al. 2004b, 2007a). Morula-stage embryos enter the uterus on days 4-6 post-mating and then form a blastocyst that contains an inner cell mass and a blastocoele or central cavity surrounded by a monolayer of trophectoderm (Guillomot 1995). After hatching from the zona pellucida, blastocysts develop into a tubular form, and then elongate on day 12 (sheep) or day 15 (cattle) to filamentous conceptuses that occupy the entire length of the uterine horn. The elongated or filamentous conceptus is composed mainly of extraembryonic trophectoderm lined with endoderm. Hatched blastocysts and trophoblastic vesicles do not elongate in vitro, but do so when transferred into the uterus of either sheep or cows (Heyman et al. 1984, Flechon et al. 1986). Progesterone acts on the uterus to indirectly stimulate pre-implantation blastocyst growth and elongation (Garrett et al. 1988a, Mann \& Lamming 2001, Mann et al. 2006, Satterfield et al. 2006). Elongation of the blastocyst is critical for developmentally regulated production of interferon $\tau$ (IFNT), the pregnancy recognition signal, and for implantation (Farin et al. 1989, Guillomot et al. 1990, Gray et al. 2002). IFNT acts in a paracrine manner on the endometrium to inhibit development of the endometrial luteolytic mechanism required for pulsatile release of prostaglandin $F 2 \alpha$ $(\mathrm{PGF} 2 \alpha)$, thereby ensuring continued production of progesterone by the ovarian corpus luteum (Thatcher et al. 1989, Spencer et al. 2007a). Additionally, IFNT stimulates a number of genes in a cell-specific manner within the endometrium that are implicated in uterine receptivity and conceptus development (Hansen et al. 1999, Spencer et al. 2007a).

Coincident with apposition and adhesion of mononuclear cells of the trophectoderm to the endometrial luminal epithelium (LE), trophoblast giant binucleate cells (BNC) differentiate within the trophectoderm (Wooding 1984) from mononucleate stem cells by consecutive nuclear divisions without cytokinesis, a phenomenon termed mitotic polyploidy (Wooding 1992). Migration of BNC to the microvillar junction and then fusion with individual LE cells produce trinucleate fetomaternal hybrid cells (Wooding 1984). Continued BNC migration and fusion with trinucleate cells, together with displacement and/or death of the remaining uterine LE, apparently produces multinucleated syncytial plaques, linked by tight junctions and limited in size to 20-25 nuclei that cover the caruncles (Wooding 1982, 1984, 1992). This caruncular syncytium, in which no nuclear division has been reported, expands in area during formation and maintenance of cotyledons, presumably deriving nuclei from continued BNC migration and fusion. The BNC have at least two main functions: (1) formation of a hybrid fetomaternal syncytium for successful implantation and subsequent cotyledonary growth in the placentome and (2) synthesis and secretion of protein and steroid hormones such as chorionic somatomammotropin hormone 1 (CSH1; alias placental lactogen) and progesterone (Wooding 1992). $\mathrm{CSH} 1$ acts on the endometrial glands of the uterus to stimulate their development and expression of genes that encode secreted proteins (Spencer et al. 2004a). In addition to trophectoderm differentiation, several other events occur during blastocyst elongation, including gastrulation of the embryo and formation of the yolk sac and allantois (Guillomot 1995), which are vital for embryonic survival and formation of a functional placenta.

\section{Hormonal regulation of endometrial function and conceptus development}

\section{Progesterone regulation of blastocyst survival and growth}

Progesterone stimulates and maintains endometrial functions necessary for conceptus growth, implantation, placentation, and development to term (see Bazer 1975, Bazer et al. 1979, Spencer \& Bazer 2002, Spencer et al. 2004a). Although blastocysts can develop entirely in vitro, the overall success of this process and quality of the blastocysts is markedly lower than in vivo (Hasler et al. 1995). Moreover, blastocysts must be transferred into a receptive uterus for growth and development into an elongated filamentous conceptus (Heyman et al. 1984, Flechon et al. 1986, Maddox-Hyttell et al. 2003). In cattle, concentrations of progesterone in early pregnancy clearly affect embryonic survival during early pregnancy (Mann \& Lamming 1999). In both lactating dairy cows and heifers, there is a strong positive association between the time that concentrations of progesterone increase in plasma and embryonic survival (Villa-Godoy et al. 1988, Larson et al. 1997, Starbuck et al. 1999). Heifers and ewes with lower concentrations of progesterone in the early luteal phase had retarded conceptuses that secreted less IFNT (Nephew et al. 1991, Mann \& Lamming 2001). Increasing concentrations of progesterone from days 2 to 5 or days 5 to 9 enhanced conceptus development and size on day 14 in heifers (Garrett et al. 1988b) and day 16 in cows (Mann et al. 2006), while animals with lower concentrations in the early luteal phase had retarded embryonic development (Nephew et al. 1991, Mann \& Lamming 2001) and 
less IFNT produced by the conceptuses (Mann \& Lamming 2001). Advancement of conceptus development by exogenous progesterone during metestrus and early diestrus has also been reported in sheep (Kleemann et al. 1994, Satterfield et al. 2006). Increasing progesterone in cattle after artificial insemination or mating increased embryonic survival (Wiltbank et al. 1956, Johnson et al. 1958, Robinson et al. 1989, van Cleef et al. 1991, Thatcher et al. 2001, Larson et al. 2007), although other studies found that progesterone augmentation had no effect on pregnancy rates in cattle and sheep (Funston et al. 2005, Howard et al. 2006). Progesterone supplementation is unlikely to rescue development of embryos with inherent genetic defects, and its efficacy may be different across breeds (beef cattle versus dairy cattle), overall fertility, and metabolic state (lactating versus dry; Mann \& Lamming 1999, Mann et al. 2001).

Although progesterone acts via the uterus to stimulate blastocyst survival and growth, the specific genes and physiological mechanisms regulated by progesterone are only now being elucidated. As summarized in Supplementary Table 1, which can be viewed online at http://www.reproduction-online.org/supplemental/, a combination of candidate gene analyses and transcriptional profiling experiments has defined a number of genes and pathways regulated by pregnancy, progesterone, and IFNT in sheep and cattle (Bauersachs et al. 2005, 2006, Chen et al. 2006, Gray et al. 2006, Klein et al. 2006). Indeed, progesterone both positively and negatively regulates expression of genes in the endometrium, and progesterone and IFNT costimulate a number of genes, particularly in the endometrial epithelium (Supplementary Table 1 and Fig. 1). As depicted in Fig. 1, temporal and spatial analyses of gene expression revealed that galectin 15 (LGALS15), cystatin C (CST3), and cathepsin L (CTSL) expression is initiated in the endometrial LE by day 12 and maintained to day 14 in both cyclic and pregnant ewes (Gray et al. 2004, Song et al. 2005, 2006a). Those genes are no longer expressed by day 16 in cyclic ewes, but their expression is further stimulated by IFNT from the conceptus in pregnant ewes. LGALS15 is implicated in blastocyst attachment and elongation (Gray et al. 2004), because functional studies of LGALS15 and other galectins have implicated these proteins in cell growth, differentiation and apoptosis, as well as in cell adhesion, chemoattraction, and migration (Yang \& Liu 2003, Farmer et al. 2007, Lewis et al. 2007). Cathepsins are peptidases that can degrade extracellular matrix, catabolize intracellular proteins, process prohormones, and regulate uterine receptivity for implantation and trophoblast invasion in several mammals (Salamonsen 1999). CST3 is an inhibitor of CTSL. A balance of proteases and their inhibitors is likely required to modify the glycocalyx on endometrial LE and trophoblast during apposition and adhesion phases of implantation (Carson et al.
2000). Similar to the human (Giudice \& Ferenczy 1996, Kao et al. 2002), endometria of both cyclic and pregnant ewes express genes implicated in uterine receptivity and blastocyst development and implantation. However, the absence of a sufficiently developed blastocyst to signal pregnancy recognition results in those genes being 'turned off' as luteolysis ensues and the ewe returns to estrus for another opportunity to mate. In addition to the upregulating genes, progesterone also downregulates a number of genes in the endometrium that can be revealed by treatment of animals with an antiprogestin (Gray et al. 2006; Supplementary Table 1).

\section{PGR regulation and endometrial gene expression}

Recent studies found that LGALS15, CTSL, and CST3 are induced by progesterone and stimulated further by IFNT (Gray et al. 2004, Song et al. 2005, 2006a, Satterfield et al. 2006). In most mammalian uteri, progesterone receptors (PGR) are expressed in endometrial epithelia and stroma during the early to mid-luteal phase, allowing direct regulation (induction or repression) of genes by progesterone. However, continuous exposure of the endometrium to progesterone negatively regulates $P G R$ expression in the LE and then glandular epithelium (GE), and the downregulation of PGR is temporally associated with the induction of many progesteronestimulated genes (Supplementary Table 1; Fig. 1). Indeed, the paradigm of loss of PGR in uterine epithelia immediately prior to implantation is common across mammals (Carson et al. 2000). In the ovine uterus, PGR protein is not detectable in LE and GE after days 11 and 13 of pregnancy respectively but can be detected in the uterine stroma and myometrium throughout gestation (Wathes \& Hamon 1993, Spencer \& Bazer 1995), suggesting that progestamedins, such as fibroblast growth factor 7 (FGF7), FGF10, and hepatocyte growth factor, from stromal cells regulate epithelial functions during most of pregnancy (Chen et al. 2000a, 2000b). In sheep, PGR loss from the uterine epithelia is determined by timing of the post-ovulatory rise in progesterone and requires continuous exposure to progesterone for at least 8 days (Spencer et al. 1995, Satterfield et al. 2006). Thus, an early increase in circulating progesterone apparently advances the timing of PGR loss from uterine epithelia (Satterfield et al. 2006). In cyclic ewes, loss of the PGR allows for induction of estrogen receptor- $\alpha$, expression of oxytocin receptors (OXTR), and development of the endometrial luteolytic mechanism (see Spencer et al. 2007 b). In pregnant ewes (Fig. 1), loss of PGR in endometrial epithelia is associated with a reduction in anti-adhesive MUC1 (mucin glycoprotein 1) and onset LGALS15, CTSL, and CST3 expression in the LE (Gray et al. 2004, Song et al. 2005, 2006a, Satterfield et al. 2006) and SPP1 (secreted phosphoprotein 1 or osteopontin), STC1 (stanniocalcin), and UTMP (uterine milk proteins or serpins) expression in the GE (Johnson et al. 


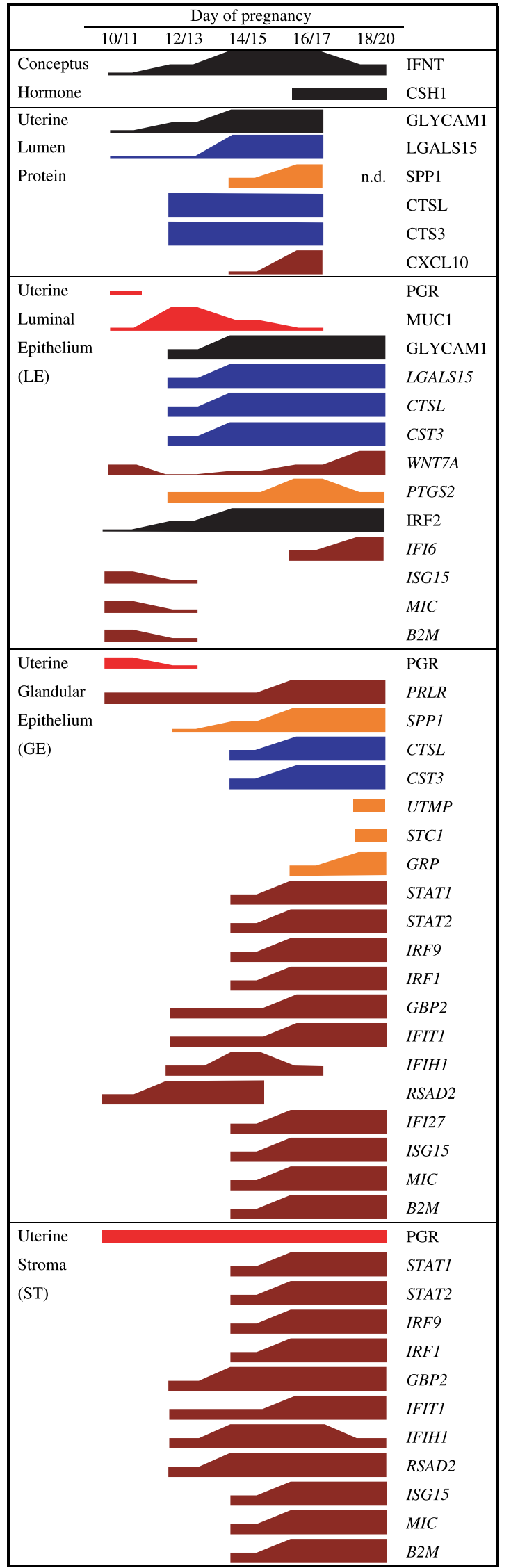

2000b, Stewart et al. 2000, Song et al. 2006b). One understudied area is what controls expression of the PGR and how PGR regulates transcription of target genes in a cell-specific manner within the uterus.

Although PGR expression is absent from endometrial LE of cattle by day 16 post-estrus/mating (Robinson et al. 2001), comparative studies on temporal and spatial alterations in gene expression in bovine uteri during the estrous cycle and early pregnancy are not available to determine whether the same genes associated with uterine receptivity and conceptus implantation in sheep are present and operative in cattle. Recent studies suggest that uterine gene expression may be spatially different from sheep. For instance, Bauersachs et al. (2005) found that UTMP mRNA levels were markedly increased at estrus when compared with diestrus with highest levels in the cranial part of the ipsilateral uterine horn. Moreover, LGALS15 was not identified in transcriptional profiling studies of early pregnancy in cattle (Bauersachs et al. 2005, 2006, Klein et al. 2006). Although the LGALS15 gene is present in sheep, cattle, and goats, it is only expressed in endometria of sheep and goats (Lewis et al. 2007). However, other lectins (LGALS9 and LGALS3BP) were identified in the uteri of cattle (Supplementary Table 1), and their transcripts were upregulated mainly in LE of pregnant cows (Bauersachs et al. 2006). Thus, one possibility is that common pathways and gene families regulate conceptus-endometrial interactions during early pregnancy across mammals, but specific genes may be different in each species (Bauersachs et al. 2006). Understanding the commonalities and differences in progesterone actions on the endometrium will require carefully conducted longitudinal and cell-specific transcriptional profiling studies.

\section{Conceptus regulation of uterine function: IFNT and placental lactogen}

Maternal recognition of pregnancy is the physiological process whereby the conceptus signals its presence to the maternal system and prolongs the lifespan of the corpus luteum (Bazer et al. 1991). In ruminants, IFNT is the pregnancy recognition signal secreted by the elongating conceptus that acts on the endometrium to inhibit development of the luteolytic mechanism (see Thatcher et al. 1989, Bazer 1992, Mann et al. 1999,

Figure 1 Temporal and spatial roadmap of progesterone- and IFNTstimulated genes in the uterus during establishment of pregnancy in sheep. The relative abundance of mRNA or protein across days of pregnancy is indicated within the uterus as well as regulation of genes by progesterone and/or IFNT. Red, downregulated by progesterone; orange, induced or stimulated by progesterone; brown, induced or stimulated by IFNT; blue, induced by progesterone and stimulated by IFNT; n.d., not determined due to inability to flush intact conceptuses from the uterine lumen on days 18-20 of pregnancy. 
Spencer \& Bazer 2004, Spencer et al. 2007b). Although IFNT inhibits OXTR expression, it does not inhibit PTGS2 (prostaglandin-endoperoxide synthase 2 (prostaglandin $\mathrm{G} / \mathrm{H}$ synthase and cyclooxygenase) prostaglandin or COX2), which is important for the generation of prostaglandins, such as PGE2 and PGI2, considered to be critical regulators of uterine receptivity and conceptus-endometrial interactions during early pregnancy (Charpigny et al. 1997a, 1997b, Arosh et al. 2004, Emond et al. 2004, Cammas et al. 2006, Critchley et al. 2006). In addition to its antiluteolytic actions, IFNT acts on the endometrium to induce or enhance expression of a number of genes (IFNT-stimulated genes or ISGs) that are hypothesized to regulate uterine receptivity and conceptus development during implantation (Hansen et al. 1999, Spencer et al. 2004b, 2007a). Given that IFNT is a member of the family of Type I IFN family (Roberts et al. 1997), one challenge is to determine which of the large number of ISGs have a specific function in conceptus-endometrial interactions given that they have traditionally been associated with cellular antiviral responses; the main function of type I IFNs is to inhibit viral infection (Pestka 2007).

\section{ISGs in the endometrium}

IFNT induces or increases expression of several ISGs in endometria that are hypothesized to be important for conceptus implantation (Hansen et al. 1999, Spencer et al. 2004b, 2007a). Since expression of ISGs increases in a stage-specific manner within endometria of diverse species, including domestic animals, laboratory rodents, primates, and humans during early pregnancy, they may be universally important in establishment of uterine receptivity to conceptus implantation ( $\mathrm{Li}$ et al. 2001, Austin et al. 2003, Cheon et al. 2003, Bany \& Cross 2006, Hess et al. 2007, Kashiwagi et al. 2007). A number of transcriptional profiling experiments conducted with human cells, ovine endometrium, and bovine endometrium have elucidated genes regulated by IFNT during pregnancy (Kim et al. 2003, Sandra et al. 2005, Bauersachs et al. 2006, Chen et al. 2006, Gray et al. 2006, Klein et al. 2006; see Supplementary Table 1 and Figs 1 and 2 for summary and interpretation).

\section{IFNT and the JAK-STAT-IRF pathway}

As illustrated in Fig. 2, IFNT activates the classical JAK-STAT-IRF (janus kinase-signal transducer and activator of transcription-interferon regulatory factor) signaling pathway used by other type I IFNs (Stark et al. 1998) in a uterine cell-specific manner. As illustrated in Figs 1-3 and summarized in Supplementary Table 1, numerous ISGs are induced or stimulated in the endometrium during conceptus elongation in both cattle and sheep. Curiously, in vivo studies revealed that many classical ISGs ( $\beta$-2-microglobulin (B2M), guanylate-binding protein 2 (GBP2), interferon, $\alpha$-inducible protein 27 (IFI27), interferon-induced protein with tetratricopeptide repeats 1 (IFIT1), interferonstimulated gene 15 (ISG15), IRF9, MHC class I polypeptide (MIC), 2',5'-oligoadenylate synthetase (OAS), radical S-adenosyl methionine domain containing 2 (RSAD2), STAT1, and STAT2) are not induced or upregulated by IFNT in endometrial LE of the ovine uterus (Johnson et al. 1999b, 2001, Choi et al. 2001, 2003, Kim et al. 2003, Song et al. 2007). This finding was initially surprising, because all endometrial cell types express IFNAR1 (interferon $(\alpha, \beta$, and $\omega$ ) receptor 1$)$ and IFNAR2 subunits of the common type I IFNAR (Rosenfeld et al. 2002). However, it was discovered that IRF2, a potent transcriptional repressor of ISGs, is expressed specifically in uterine LE to repress transcriptional activity of IFNstimulated response element (ISRE)-containing promoters (Choi et al. 2001). Thus, IRF2 in LE appears to restrict IFNT induction of many ISGs to stroma and GE of the ovine uterus (Figs 1 and 2). In fact, all components of the ISGF3 transcription factor complex (STAT1, STAT2, and IRF9) and other classical ISGs (B2M, GBP2, IFI27, IFIT1, ISG15, $M I C$, and OAS) contain one or more ISREs in their promoters. Further, suppressor of cytokine signaling (SOCS1-3) are also upregulated in endometria by pregnancy and IFNT (Sandra et al. 2005). Depending on their cell-specific expression in the uterus, SOCS1-3 may be involved in negative regulation of the JAK-STAT pathway activated by IFNT (Kile et al. 2002). The silencing of $M I C$ and $B 2 M$ genes in endometrial LE during pregnancy may be a critical mechanism preventing immune rejection of the conceptus semi-allograft (Choi et al. 2003). Of particular note, several reports indicate induction or increases in ISGs in peripheral blood lymphocytes and the corpus luteum during pregnancy or in ewes receiving intrauterine injections of IFNT (Spencer et al. 1999a, Yankey et al. 2001, Gifford et al. 2007). Thus, IFNT or IFNT-stimulated immune cells may traffic out of the uterus to exert systemic effects that alter maternal physiology, particularly the corpus luteum of pregnancy.

Given that the critical signaling components of the JAK-STAT signaling system (STAT1, STAT2, IRF9) are not expressed in endometrial LE, IFNT must utilize a nonclassical STAT1-independent cell signaling pathway to regulate expression of genes in endometrial LE of the ovine uterus (Fig. 2). Transcriptional profiling of human U3A (STAT1 null) cells and ovine endometrium treated with IFNT were used to discover novel ISGs in the endometrial LE during pregnancy including WNT7A (wingless-type MMTV integration site family, member 7A), LGALS15, CTSL, and CST3 (Kim et al. 2003, Song et al. 2005, 2006a, Gray et al. 2006). The expression patterns of novel and classical ISGs are summarized in Figs 1 and 2. Functional aspects of a few IFNT-stimulated genes will be discussed, and the reader is referred to several reviews with additional information on other 

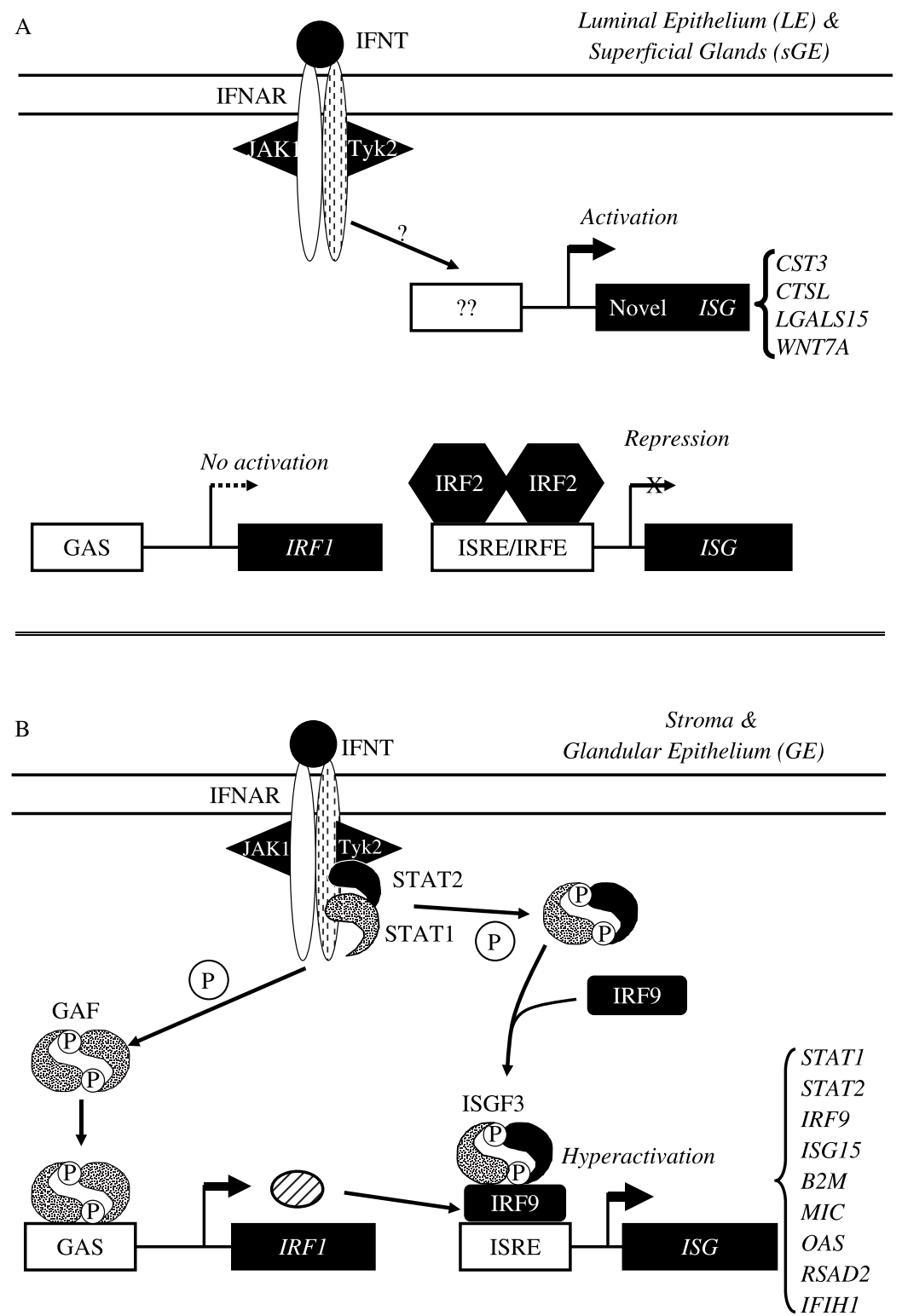

Figure 2 Schematic of current working hypothesis on cell-specific IFNT signaling in the endometrium of the ovine uterus. IFNT, produced by developing conceptuses of ruminants, binds to IFNAR present on cells of the ovine endometrium. (A) In the uterine luminal and superficial glandular epithelia (LE/sGE), IRF2, a potent and stable transcriptional repressor, increases during early pregnancy. The continual presence of IRF2 inhibits classical IFN-stimulated genes or ISGs (STAT1, STAT2, IRF9, B2M, ISG15, MHC, and OAS) through direct ISRE and IRFE binding and coactivator repulsion. Thus, critical factors in the classical JAK-STAT-IRF pathway (STAT1, STAT2, and IRF9) are not present, resulting in the absence of ISGF3 or IRF1 transcription factors necessary to transactivate ISGs. However, IFNT does activate an unknown cell signaling pathway that results in induction of $W N T 7 A$ and stimulation of non-classical IFNT-stimulated genes (CST3, CTSL, and LGALS15) specifically in LE/sGE. (B) In cells of the stroma (ST) and middle to deep GE, the IRF2 repressor is not expressed. Thus, IFNT-mediated association of IFNAR subunits facilitates cross-phosphorylation and activation of JAK1 and Tyk2, which in turn phosphorylates the receptor and creates a docking site for STAT2. STAT2 is then phosphorylated, thus creating a docking site for STAT1 which is then phosphorylated. STAT1 and STAT2 are then released from the receptor and can form two transcription factor complexes, GAF and ISGF3. ISGF3 is formed by association of a STAT1-2 heterodimer and IRF9 in the cytoplasm, translocates to the nucleus, and transactivates genes containing an ISRE(s), such as STAT1, STAT2, IRF9, B2M, ISG15, MIC, and OAS. GAF is formed by STAT1 homodimers, which translocates to the nucleus and transactivates genes containing a GAS element(s) such as IRF1. IRF1 can also bind and transactivate ISRE-containing genes as well as IRFE-containing genes. The simultaneous induction of STAT2 and IRF9 by IFNT appears to shift transcription factor formation from GAF towards predominantly ISGF3. Therefore, IFNT activation of the JAK-STATIRF signal transduction pathway allows for constant formation of ISGF3 and GAF transcription factor complexes and hyperactivation of ISG expression in the ST and GE. B2M, $\beta$-2-microglobulin; CST3, cystatin C; CTSL, cathepsin L; GAF, $\gamma$-activated factor; GAS, $\gamma$ activation sequence; IFNAR, type I IFN receptor; IFNT, interferon $\tau$; IRF1, interferon regulatory factor 1; IRF2, interferon regulatory factor 2; IRFE, IRF-response element; IRF9, IFN regulatory factor 9 (alias ISGF3G); ISG15, (ISG15 ubiquitin-like modifier; alias IFI15 or UCRP); ISRE, IFN-stimulated response element; JAK, janus kinase; LGALS15, galectin 15; $\mathrm{MIC}, \mathrm{MHC}$ class I polypeptide-related sequence; OAS, 2', 5' -oligoadenylate synthetases; STAT1, signal transducer and activator of transcription 1, $91 \mathrm{kDa}$; STAT2, signal transducer and activator of transcription 2, $113 \mathrm{kDa}$; WNT7A, wingless-type MMTV integration site family, member 7A. 


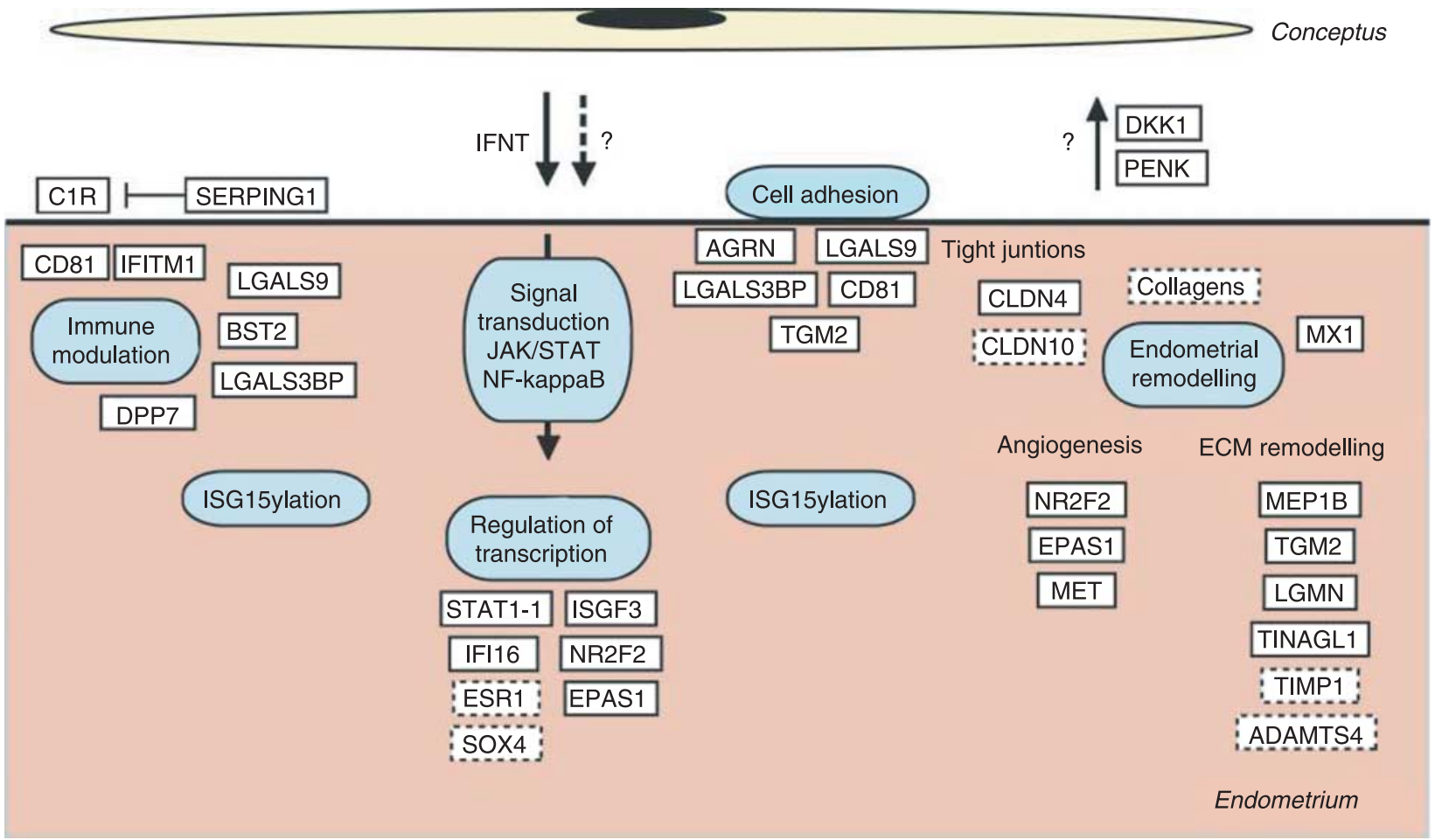

Figure 3 Model for conceptus-endometrium interactions in the bovine preattachment period. Differential transcriptome analysis of endometrium samples from day 18 pregnant as compared with non-pregnant heifers identified biological processes which are likely to be important for implantation and maintenance of pregnancy. These include IFNT signaling, embryo-maternal immune modulation, cell adhesion, and remodeling of the endometrium to prepare for implantation of the embryo. Genes in solid boxes, upregulated in the endometrium of pregnant animals; genes in dashed boxes, downregulated in the endometrium of pregnant animals. STAT1-1, STAT1 homodimers; ISGF3, transcription factor complex consisting of STAT1/STAT2 heterodimer and IRF9 (from Bauersachs et al. 2006).

genes (Spencer et al. 2004a, 2004b, 2007a, 2007b, Bauersachs et al. 2005, 2006).

\section{ISG15}

Many classical ISGs, such as ISG15, are expressed in LE of the ovine uterus on days 10 or 11 of the estrous cycle and pregnancy, but are undetectable in LE by days 12-13 (Johnson et al. 1999b; see Figs 1 and 2). In response to IFNT from elongating conceptuses, ISG15 is induced in the stratum compactum stroma and GE by days 13-14, and expression extends to the stratum spongiosum stroma, deep glands, and myometrium as well as resident immune cells of the ovine uterus by days 15-16 of pregnancy (Johnson et al. 1999b, 2000a). As IFNT production by the conceptus declines, expression of ISGs also declines, but some remain abundant in endometrial stroma and GE on days 18-20 of pregnancy. Similar temporal and spatial alterations in ISG15 expression occur in the bovine uterus during early pregnancy (Johnson et al. 1999a, Austin et al. 2004).

\section{WNT7A}

During early pregnancy in sheep (Fig. 1), WNT7A is present on day 10 , downregulated on day 12 , and then induced by IFNT between days 12 and 14 of pregnancy specifically in LE (Kim et al. 2003). The WNT family (19 genes in human) includes many highly conserved and secreted glycoproteins that regulate cell and tissue growth and differentiation during embryonic development and play a central role in coordinating uterineconceptus interactions required for implantation in mice and perhaps humans (Mohamed et al. 2005). WNT7A activates the canonical WNT signaling pathway in ovine trophectoderm cells and likely plays a role in regulating gene expression, proliferation, and perhaps BNC differentiation (Nakano et al. 2005, Hayashi et al. 2007). Further, WNT7A may have autocrine effects on LE to regulate expression of target genes important for uterine receptivity and conceptus implantation, such as LGALS15, CST3, and CTSL.

\section{LGALS15}

Similar to CTSL and CST3 (Fig. 1), LGALS15 is induced by progesterone in LE between days 10 and 14 and is further increased by IFNT (Gray et al. 2004). Galectins are proteins with a conserved carbohydrate recognition domain that bind $\beta$-galactosides, thereby cross-linking glycoproteins as well as glycolipid receptors on the surface of cells, such as integrins, and initiating biological responses (Yang \& Liu 2003). LGALS15, 
originally termed ovgal11, was originally identified in ovine intestinal epithelium as being induced in response to infection by the nematode parasite Haemonchus contortus (Dunphy et al. 2000). Interestingly, LGALS15 is the $14 \mathrm{~K}$ protein from sheep endometrium initially characterized as a progesterone-induced protein associated with crystalline inclusion bodies in uterine epithelia and conceptus trophectoderm (Kazemi et al. 1990). LGALS15 is implicated in conceptus implantation (Spencer et al. 2004b, 2007a), because functional studies of other galectins have implicated these proteins in cell growth, differentiation, and apoptosis as well as in cell adhesion, chemoattraction, and migration (Yang \& Liu 2003). Recently, Farmer et al. (2007) found that LGALS15 stimulates migration and adhesion of ovine trophectoderm cells via activation of Jun $\mathrm{N}$-terminal kinase and integrin signaling respectively. Of particular relevance to this review paper, the LGALS15 gene is present in both sheep and cattle but not humans, mice, or other sequenced species, and the gene is only expressed in the endometrium of sheep and goats (Lewis et al. 2007).

\section{CXCL10}

A classical ISG with reported biological effects on trophectoderm growth and adhesion in ruminants is CXCL10 (chemokine (C-X-C motif) ligand 10; alias IP-10; Nagaoka et al. 2003a, 2003b). CXCL10 is a member of the $\mathrm{C}-\mathrm{X}-\mathrm{C}$ chemokine family that regulates multiple aspects of inflammatory and immune responses primarily through chemotactic activity toward subsets of leukocytes. CXCL10 mRNA was localized to monocytes in the subepithelial stroma of uteri from pregnant, but not cyclic ewes. Whether IFNT directly regulates CXCL10 in the monocytes or simply attract monocytes to the endometrium remains to be determined. In the ovine uterus, CXCL10 appeared on day 17 in the uterine lumen, and the CXCR3 receptor was localized to trophectoderm (Fig. 1). Subsequently, recombinant CXCL10 was shown to stimulate migration of trophectoderm cells and promote their adhesion to fibronectin, as well as increase expression of integrins $\alpha 5, \alpha \mathrm{V}$, and $\beta 3$ subunit mRNAs (Nagaoka et al. 2003a, Imakawa et al. 2006). Integrins are essential for conceptus implantation (see Burghardt et al. 2002). In the human, chemokines are expressed by maternal and embryonic cells during implantation, whereas corresponding receptors are on trophoblast cells (Hannan et al. 2006). Further, trophoblast migration is promoted by chemokines and endometrial cell-conditioned medium indicating an important involvement of chemokines in maternal-fetal communication (Lea \& Sandra 2007).

\section{ISG differences in bovine and sheep uteri}

Many ISGs are induced or upregulated in endometria of pregnant cattle and sheep; however, there may be cell-specific differences in expression between these species. For instance (Supplementary Table 1), mRNAs of several pregnancy- and IFN-stimulated genes (AGRN (agrin), BST2 (bone marrow stromal cell antigen 2), C1R, C1S, IFITM3, LGALS3BP, LGALS9, PARP12, SERPING1, ubiquitin-activating enzyme-1-like protein (UBE1L), USP18, and XAF1) are found in endometrial LE of day 18 pregnant cattle (Bauersachs et al. 2006, Klein et al. 2006). However, ISG15 is not stimulated or present in endometrial LE of early pregnant cows or ewes, but is markedly upregulated in the stroma and GE (Johnson et al. 1999a, 1999b, 2000a). ISG15 encodes a ubiquitinlike protein that can be conjugated to intracellular proteins, such as phospholipase C- $\gamma 1$, JAK1, extracellular regulated kinase 1, and STAT1. Austin et al. (2004) postulated that one function of ISG15 is to stabilize proteins rather than target them to degradation as described for polyubiquitination. This is consistent with the fact that conjugated ISG15 remains in the uterus as late as day 45 of pregnancy. Interestingly, the gene for bovine UBE1L, the initiating enzyme for ISG15ylation, was also identified as an upregulated gene in endometrium from day 18 pregnant cows (Rempel et al. 2005). Furthermore, the mRNAs of IFITM1 and IFITM3, encoding proteins hypothesized to possess E2 ubiquitin-conjugating enzyme activity that is involved in protein ubiquitylation, were also upregulated in endometrium from pregnant cattle, supporting an important role for ISG15ylation in establishment and maintenance of pregnancy (Fig. 2; Klein et al. 2006). Comparative studies on temporal and spatial alterations in gene expression in bovine uteri during the estrous cycle and early pregnancy are underway to determine whether the genes associated with uterine receptivity and conceptus implantation in sheep are present and operative in cattle.

\section{$\mathrm{CSH} 1$ regulation of uterine gland morphogenesis and secretory function}

During early pregnancy, ovine and bovine uteri are exposed sequentially to estrogen, progesterone, IFNT, and $\mathrm{CSH} 1$, which is proposed to initiate and maintain endometrial gland morphogenesis and differentiated secretory functions (for review see Spencer et al. 1999b, 2004a, Spencer \& Bazer 2002). Placentae of many species, including rodents, humans, nonhuman primates, and ruminants, secrete hormones structurally related to pituitary prolactin (PRL) and growth hormone $(\mathrm{GH})$ that are termed $\mathrm{CSH} 1$ (alias placental lactogen; Soares 2004). Ovine CSH1 is produced by trophoblast giant $\mathrm{BNC}$ from days 15 to 16 of pregnancy, which is coordinated with onset of expression of UTMP, SPP1, gastrin-releasing peptide (GRP), and STC1 (Ing et al. 1989, Whitley et al. 1998, Stewart et al. 2000, Song et al. 2006b), which are excellent markers for GE differentiation and secretory function during pregnancy in sheep (Fig. 1). Surprisingly, bovine STC1 and GRP mRNA levels 
were higher in endometrium from day 18 cyclic than day 18 pregnant cows (Bauersachs et al. 2006), suggesting species-specific control of expression of these genes. A homodimer of the PRL receptor (PRLR), as well as a heterodimer of PRLR and $\mathrm{GH}$ receptor, transduce signals by ovine CSH1/placental lactogen (Gertler \& Djiane 2002). In the ovine uterus, PRLR gene expression is unique to GE (Cassy et al. 1999, Stewart et al. 2000). Temporal changes in circulating levels of $\mathrm{CSH} 1$ are correlated with endometrial gland hyperplasia and hypertrophy and increased production of SPP1 and UTMP during pregnancy (Supplementary Table 1). Sequential exposure of the pregnant ovine endometrium to progesterone, IFNT, and CSH1 appears to be required to activate and maintain endometrial remodeling, secretory function of GE, and perhaps uterine growth during gestation. Chronic treatment of ovariectomized ewes with progesterone induces SPP1, UTMP, and STC1 expression by GE (Moffatt et al. 1987, Spencer et al. 1999b, Johnson et al. 2000b, Song et al. 2006b). However, intrauterine infusions of $\mathrm{CSH} 1$ further increases endometrial SPP1, STC1, and UTMP gene expression, but only when ewes receive progesterone and intrauterine infusions of IFNT (Spencer et al. 1999b, Noel et al. 2003). The effects of IFNT may be attributed, in part, to increasing PRLR in the endometrial glands (Martin et al. 2004). Available evidence indicates that placental hormones play key roles in stimulating endometrial gland morphogenesis and differentiated functions during pregnancy that are required for conceptus development in ruminants.

\section{Models and approaches for studying conceptus- endometrial interactions}

\section{Genomics}

Several groups have used differential display and subtractive hybridization to identify differentially expressed genes in the endometrium that were subsequently arrayed for transcriptional profiling experiments (Spencer et al. 1999c, Bauersachs et al. 2005, 2006, Klein et al. 2006). Further, custom arrays from the endometrium have been made for transcriptional profiling experiments in sheep (Chen et al. 2006, Gray et al. 2006) and cattle (Bauersachs et al. 2007). The advent of commercially available bovine arrays from the bovine oligo microarray consortium (www.bovineoligo.org) and commercial companies should enhance research profiling gene expression in ruminant embryos and endometria. Given that endometrial gene expression changes in response to progesterone and the conceptus in a temporal and cell-specific manner (Fig. 1), days of the estrus cycle and pregnancy status should be chosen carefully. Further, the ruminant endometrium has caruncular and intercaruncular areas with varying amounts of different cell types, including LE, GE, stroma, blood and lymph vessels, and immune cells. Therefore, transcriptional profiling of individual cell populations may be warranted and accomplished using laser capture microdissection (Niklaus \& Pollard 2006). These studies should elucidate temporal and spatial changes in gene expression that occur in specific endometrial and conceptus cell types during pregnancy. Another important point is the developmental potential of the conceptus, which will have important effects on the molecular responses of the maternal environment, but is difficult to predict. Recently, it was proposed to develop transgenic reporter systems which facilitate monitoring of important steps in development in living embryos (Habermann et al. 2007). For instance, a Pou5f1-EGFP reporter gene allows quantitative monitoring of pluripotency gene activation after somatic cell nuclear transfer (SCNT) in cattle (Wuensch et al. 2007). This system will be an important tool to evaluate whether placental abnormalities, which are a major reason for pregnancy loss after transfer of SCNT embryos, result from disturbed embryo-maternal communication. Advanced bioinformatic analyses of these data should reveal gene networks and biological pathways involved in physiological and pathological conceptus-endometrial interactions. Further, they are critical to understanding the bases for polygenic traits such as uterine capacity.

\section{Proteomics and metabolomics}

In addition to genomics, proteomic and metabolomic analyses are required to understand conceptus-endometrial interactions due to the nature of histotroph, defined as tropic substances of tissue origin, present in the uterine lumen that impacts conceptus growth throughout pregnancy. All mammalian uteri contain endometrial epithelia that synthesize and secrete or transport a complex and rather undefined mixture of amino acids, ions, glucose, enzymes, growth factors, hormones, transport proteins, and other substances termed histotroph (Bazer 1975). The epithelial cells of the uterine lumen are highly secretory during implantation, and the trophectoderm exhibits intense pinocytotic activity which increases as the conceptus develops (Guillomot 1995). Therefore, factors supporting growth of pre- and peri-implantation blastocysts and elongating conceptuses are likely obtained from uterine histotroph (Lee et al. 1998). This hypothesis is supported by results from studies of asynchronous uterine transfer of embryos and trophoblast vesicles (Lawson et al. 1983, Flechon et al. 1986) and from studies of uterine gland knockout (UGKO) ewes (Gray et al. 2001b, 2002).

The UGKO ewe model is produced by continuous administration of a synthetic, non-metabolizable progestin to neonatal ewes from birth to postnatal day 56 (Gray et al. 2000a). This inappropriate exposure of ewe lambs to a progestin permanently ablates differentiation and development of the endometrial glands from 
LE and produces an UGKO phenotype without apparent alterations in development of myometrium, or other Müllerian duct-derived female reproductive tract structures, or function of the hypothalamic-pituitaryovarian axis (Gray et al. 2000b, 2001a). The UGKO endometrium is devoid of glands and has markedly reduced LE surface area. UGKO ewes exhibit recurrent early pregnancy loss as blastocyst fails to elongate, and transfer of blastocysts from uteri of control ewes into uteri of timed recipient UGKO ewes does not ameliorate this defect (Gray et al. 2001b). Morphologically normal blastocysts are present in uterine flushes of bred UGKO ewes on days 6 and 9 post-mating, but not on day 14 (Gray et al. 2001b, 2002) when uteri contain either no conceptus or a severely growth-retarded tubular conceptus. Similarly, exposure of neonatal heifers to progestins alters uterine development and reduces pregnancy success in adult cows (Bartol et al. 1995). These results demonstrate that histotroph from endometrial epithelia are required for peri-implantation blastocyst survival and elongation in sheep and likely cattle.

Defects in blastocyst survival and elongation in UGKO ewes are not due to alterations in expression of steroid receptors, anti-adhesive $\mathrm{MUC1}$, adhesive integrins on the endometrial LE, or responsiveness of the endometrium to IFNT (Gray et al. 2000a, 2002). However, uterine flushes from day 14 bred UGKO ewes contain either very low or undetectable amounts of LGALS15, glycosylated cell adhesion molecule 1, and SPP1, which are adhesion proteins secreted by the uterine LE and GE that are abundant in uterine luminal histotroph of control ewes (Gray et al. 2002, 2004, 2006). Therefore, the reduction or absence of adhesion proteins from endometrial GE is a likely cause of recurrent pregnancy loss in UGKO ewes. Other essential, but as yet undefined, components of histotroph are undoubtedly absent or reduced in the uteri of infertile UGKO ewes.

The complex nature of histotroph in the uterine lumen makes it very amenable to analyses by proteomics and metabolomics. Indeed, components of histotroph come from genes expressed in the endometrium and conceptus, as well as components of serum that are selectively and specifically transported by the endometrium into the uterine lumen. Proteomic analyses of uterine histotroph from ewes and cows identified a number of proteins (Bartol et al. 1985a, 1985b, Lee et al. 1998). Pregnancy and progesterone also alter tight and adherens junctions that likely impact histotroph transport and sequestration in the uterine lumen (Satterfield et al. 2007). Increased knowledge of the bovine proteome coupled with non-gel-based qualitative and quantitative proteomic approaches utilizing mass spectrometry should enable researchers to rapidly identify proteins in uterine histotroph. Of particular interest, Berendt et al. (2005) used this approach to identify several endometrial proteins ( $\rho$ GDP dissociation inhibitor $\beta$ (ARHGDIB); 20 $\alpha$-hydroxysteroid dehydrogenase (AKR1C1); soluble $\operatorname{NADP}(+)$-dependent isocitrate dehydrogenase 1 ; and acyl-CoA-binding protein) involved in conceptusmaternal interactions. Interestingly, monozygotic twins in cattle (generated by embryo splitting) were used as a model to eliminate genetic variability as a source for proteome differences. Indeed, proteomics approaches have identified biomarkers of uterine receptivity, such as the immunophilin FK506-binding protein 4, and reproductive tract dysfunction and disease in other species (Daikoku et al. 2005, Dasari et al. 2007).

In addition to proteins, uterine histotroph contains amino acids, sugars, and lipids which have not been well studied in ruminants. In pigs, distinct changes in amino acids, lipids, and sugars occur in the uterine lumen and fetal fluids (Geisert et al. 1982, Kwon et al. 2003a, $2003 \mathrm{~b}$ ). Glucose and amino acids have a recognized role in pre-implantation embryo development (Leese 1995, Devreker \& Englert 2000), and recently amino acid transport and amino acids have been implicated in blastocyst implantation and trophectoderm differentiation via modulation of nutrient-sensing pathways (Martin \& Sutherland 2001, Martin et al. 2003). Further, lipids and their metabolites are involved endometrial function and placental development in mice and humans (Schaiff et al. 2006, 2007). The accessibility of the ruminant reproductive tract and size of the uterus should make it an attractive model for proteomic and metabolomic studies of conceptus-endometrial interactions that is not as feasible in mice and humans.

\section{Integrative systems biology and holistic approaches}

For the past several decades, reproductive biologists have endeavored to dissect out the individual genes and pathways regulating certain facets of endometrial function, conceptus development, and influences of the conceptus on endometrial function. This reductionist approach has yielded much knowledge about pregnancy recognition in which the conceptus signals its presence to the mother in order to ensure survival of the corpus luteum. However, conceptus-endometrial interactions are complex and not determined by a single gene. Therefore, a systems biology approach integrating multiple levels of information (genome, epigenome, transcriptome, proteome, interactome, etc.) is necessary to understand the biology of complex physiological systems that dictate uterine capacity, conceptus development, and maternal adaptations to pregnancy.

Holism (from Ó̀os holos, a Greek word meaning all, entire, total) is a theory that the universe and especially living nature is correctly seen in terms of interacting whole systems that are more than the mere sum of elementary parts (http://en.wikipedia.org/wiki/Holism). Thus, the properties of a given system cannot be determined or explained by the sum of its component parts alone. Instead, the system as a whole determines in 
an important way how the parts behave. Holistic approaches relate to or are concerned with whole or complete systems rather than with the analysis of, treatment of, or dissection into parts. Reductionism is sometimes seen as the opposite of holism. Reductionism in science says that a complex system can be explained by reduction to its fundamental parts. Holism and reductionism can also be regarded as complementary viewpoints, in which case both are needed to understand a given system. Integration of reductionistic and holistic approaches using systems biology and bioinformatics is expected to reveal truly novel insights into conceptusendometrial interactions.

\section{Conclusions and future directions}

During the past decade, knowledge of mechanisms and factors regulating conceptus implantation in mammals has benefited from studies of sheep, cattle, and domestic animals. However, much remains to be discovered about interactions that regulate blastocyst implantation. Our knowledge of the cellular and molecular mechanisms of blastocyst and conceptus differentiation is very limited. As illustrated in Figs 1-3 and summarized in Supplementary Table 1, a number of potential adhesion factors and cascades are proposed to regulate implantation in cattle and sheep. These adhesion systems probably function only if in the correct spatio-temporal sequence (Aplin 1997). Results from studies of rodents firmly support the hypothesis that implantation involves a multiplicity of receptor-ligand interactions that are organized into a cascade. Therefore, the individual and integrative roles of adhesion factors will need to be mechanistically determined using in vivo, ex vivo, and in vitro experiments. Although gene knockouts and transgenics are technically possible in domestic animals, these techniques are not routinely feasible as research tools to understand the specific roles of factors proposed to regulate implantation. Therefore, other strategies must be employed to conduct hypothesis-based research to determine the specific roles of candidate genes regulating implantation in domestic animals. Promising technologies include the use of lentiviral vectors, antisense oligodeoxynucleotides, morpholinos, and small inhibitory RNAs that could be used in vivo and ex vivo to perform gain-of-function and loss-of-function studies of specific gene(s) in endometrial epithelia and trophoblast (Hofmann et al. 2004, Dunlap et al. 2006, Golding et al. 2006). Future research with sheep and other domestic animals must incorporate these types of approaches to determine mechanistic roles of specific factors hypothesized to mediate implantation. The sequencing of genomes of domestic animals is expected to generate knowledge and reagents useful to understand the bases of enhanced fertility in specific breeds of domestic animals (Finnish Landrace sheep and Meishan pigs) as well as infertility (Holstein dairy cattle). Understanding of key signals that regulate uterine receptivity and implantation can be used to diagnose and identify the cause(s) of recurrent pregnancy loss and improve pregnancy rates in mammals.

\section{Declaration of interest}

The authors declare that there is no conflict of interest that would prejudice the impartiality of this scientific work.

\section{Funding}

Our studies have been generously supported by grants from the National Research Initiative Competitive Grant Program of the United States Department of Agriculture Cooperative State Research, Education, and Extension Service and National Institutes of Health; the European EMBIC network (contract no. 512040) and French National Institute for Agricultural Research (INRA); and the German Research Council (DFG), the Bavarian Research Foundation (BFS), and the German Federal Ministry of Science (BMBF). This article is based on research presented at the 2nd International Meeting on Mammalian Embryogenomics, which was sponsored by the Organisation for Economic Co-operation and Development (OECD), Le conseil Régional Ile-de-France, the Institut National de la Recherche Agronomique (INRA), Cogenics-Genome Express, Eurogentac, Proteigene, Sigma-Aldrich France and Diagenode sa. All authors declare that they have no relationship with any of the meeting sponsors.

\section{Acknowledgements}

We thank the present and past members of our laboratories and our colleagues who contributed to the research presented in this review.

\section{References}

Aplin JD 1997 Adhesion molecules in implantation. Reviews of Reproduction 2 84-93.

Arosh JA, Banu SK, Kimmins S, Chapdelaine P, MacLaren LA \& Fortier MA 2004 Effect of interferon- $\tau$ on prostaglandin biosynthesis, transport, and signaling at the time of maternal recognition of pregnancy in cattle: evidence of polycrine actions of prostaglandin E2. Endocrinology 145 5280-5293.

Austin KJ, Bany BM, Belden EL, Rempel LA, Cross JC \& Hansen TR 2003 Interferon-stimulated gene-15 (Isg15) expression is up-regulated in the mouse uterus in response to the implanting conceptus. Endocrinology 144 3107-3113.

Austin KJ, Carr AL, Pru JK, Hearne CE, George EL, Belden EL \& Hansen TR 2004 Localization of ISG15 and conjugated proteins in bovine endometrium using immunohistochemistry and electron microscopy. Endocrinology 145 967-975.

Bany BM \& Cross JC 2006 Post-implantation mouse conceptuses produce paracrine signals that regulate the uterine endometrium undergoing decidualization. Developmental Biology 294 445-456.

Bartol FF, Roberts RM, Bazer FW \& Thatcher WW 1985a Characterization of proteins produced in vitro by bovine endometrial explants. Biology of Reproduction 33 745-759.

Bartol FF, Roberts RM, Bazer FW, Lewis GS, Godkin JD \& Thatcher WW $1985 b$ Characterization of proteins produced in vitro by periattachment bovine conceptuses. Biology of Reproduction 32 681-693. 
Bartol FF, Johnson LL, Floyd JG, Wiley AA, Spencer TE, Buxton DF \& Coleman DA 1995 Neonatal exposure to progesterone and estradiol alters uterine and morphology and luminal protein content in adult beef heifers. Theriogenology 43 835-844.

Bauersachs S, Ulbrich SE, Gross K, Schmidt SE, Meyer HH, Einspanier R, Wenigerkind H, Vermehren M, Blum H, Sinowatz F et al. 2005 Gene expression profiling of bovine endometrium during the oestrous cycle: detection of molecular pathways involved in functional changes. Journal of Molecular Endocrinology 34 889-908.

Bauersachs S, Ulbrich SE, Gross K, Schmidt SE, Meyer HH, Wenigerkind H, Vermehren M, Sinowatz F, Blum H \& Wolf E 2006 Embryo-induced transcriptome changes in bovine endometrium reveal species-specific and common molecular markers of uterine receptivity. Reproduction 132 319-331.

Bauersachs S, Mitko K, Blum H \& Wolf E 2007 BOE Array Version 1: a tailored tool for studying bovine endometrium biology and pathophysiology. Journal of Dairy Science 90 4420-4423.

Bazer FW 1975 Uterine protein secretions: relationship to development of the conceptus. Journal of Animal Science 41 1376-1382.

Bazer FW 1992 Mediators of maternal recognition of pregnancy in mammals. Proceedings of the Society for Experimental Biology and Medicine 199 373-384.

Bazer FW, Roberts RM \& Thatcher WW 1979 Actions of hormones on the uterus and effect on conceptus development. Journal of Animal Science 49 35-45.

Bazer FW, Thatcher WW, Hansen PJ, Mirando MA, Ott TL \& Plante C 1991 Physiological mechanisms of pregnancy recognition in ruminants. Journal of Reproduction and Fertility 43 39-47.

Berendt FJ, Frohlich T, Schmidt SE, Reichenbach HD, Wolf E \& Arnold GJ 2005 Holistic differential analysis of embryo-induced alterations in the proteome of bovine endometrium in the preattachment period. Proteomics 5 2551-2560.

Burghardt RC, Johnson GA, Jaeger LA, Ka H, Garlow JE, Spencer TE \& Bazer FW 2002 Integrins and extracellular matrix proteins at the maternal-fetal interface in domestic animals. Cells, Tissues, Organs 171 202-217.

Cammas L, Reinaud P, Bordas N, Dubois O, Germain G \& Charpigny G 2006 Developmental regulation of prostacyclin synthase and prostacyclin receptors in the ovine uterus and conceptus during the periimplantation period. Reproduction 131 917-927.

Carson DD, Bagchi I, Dey SK, Enders AC, Fazleabas AT, Lessey BA \& Yoshinaga K 2000 Embryo implantation. Developmental Biology 223 217-237.

Cassy S, Charlier M, Guillomot M, Pessemesse L \& Djiane J 1999 Cellular localization and evolution of prolactin receptor mRNA in ovine endometrium during pregnancy. FEBS Letters 445 207-211.

Charpigny G, Reinaud P, Tamby JP, Creminon C \& Guillomot M 1997a Cyclooxygenase-2 unlike cyclooxygenase- 1 is highly expressed in ovine embryos during the implantation period. Biology of Reproduction $\mathbf{5 7}$ 1032-1040.

Charpigny G, Reinaud P, Tamby JP, Creminon C, Martal J, Maclouf J \& Guillomot M 1997b Expression of cyclooxygenase-1 and -2 in ovine endometrium during the estrous cycle and early pregnancy. Endocrinology $1382163-2171$

Chen C, Spencer TE \& Bazer FW 2000a Expression of hepatocyte growth factor and its receptor c-met in the ovine uterus. Biology of Reproduction 62 1844-1850.

Chen C, Spencer TE \& Bazer FW 2000b Fibroblast growth factor-10: a stromal mediator of epithelial function in the ovine uterus. Biology of Reproduction 63 959-966.

Chen Y, Green JA, Antoniou E, Ealy AD, Mathialagan N, Walker AM, Avalle MP, Rosenfeld CS, Hearne LB \& Roberts RM 2006 Effect of interferon- $\tau$ administration on endometrium of nonpregnant ewes: a comparison with pregnant ewes. Endocrinology 147 2127-2137.

Cheon YP, Xu X, Bagchi MK \& Bagchi IC 2003 Immune-responsive gene 1 is a novel target of progesterone receptor and plays a critical role during implantation in the mouse. Endocrinology 144 5623-5630.

Choi Y, Johnson GA, Burghardt RC, Berghman LR, Joyce MM, Taylor KM, Stewart MD, Bazer FW \& Spencer TE 2001 Interferon regulatory factortwo restricts expression of interferon- stimulated genes to the endometrial stroma and glandular epithelium of the ovine uterus. Biology of Reproduction 65 1038-1049.
Choi Y, Johnson GA, Spencer TE \& Bazer FW 2003 Pregnancy and interferon tau regulate $\mathrm{MHC}$ class I and beta-2-microglobulin expression in the ovine uterus. Biology of Reproduction 68 1703-1710.

van Cleef J, Drost M \& Thatcher WW 1991 Effects of post-insemination progesterone supplementation on fertility and subsequent oestrus responses of dairy heifers. Theriogenology 36 795-807.

Critchley HO, Osei J, Henderson TA, Boswell L, Sales KJ, Jabbour HN \& Hirani N 2006 Hypoxia-inducible factor-1alpha expression in human endometrium and its regulation by prostaglandin E-series prostanoid receptor 2 (EP2). Endocrinology 147 744-753.

Daikoku T, Tranguch S, Friedman DB, Das SK, Smith DF \& Dey SK 2005 Proteomic analysis identifies immunophilin FK506 binding protein 4 (FKBP52) as a downstream target of Hoxa10 in the periimplantation mouse uterus. Molecular Endocrinology 19 683-697.

Dasari S, Pereira L, Reddy AP, Michaels JE, Lu X, Jacob T, Thomas A, Rodland M, Roberts CT Jr, Gravett MG et al. 2007 Comprehensive proteomic analysis of human cervical-vaginal fluid. Journal of Proteome Research 6 1258-1268.

Devreker F \& Englert Y 2000 In vitro development and metabolism of the human embryo up to the blastocyst stage. European Journal of Obstetrics and Gynecology 92 51-56.

Diskin MG, Murphy JJ \& Sreenan JM 2006 Embryo survival in dairy cows managed under pastoral conditions. Animal Reproduction Science $\mathbf{9 6}$ 297-311.

Dunlap KA, Palmarini M, Varela M, Burghardt RC, Hayashi K, Farmer JL \& Spencer TE 2006 Endogenous retroviruses regulate periimplantation placental growth and differentiation. PNAS 103 14390-14395.

Dunphy JL, Balic A, Barcham GJ, Horvath AJ, Nash AD \& Meeusen EN 2000 Isolation and characterization of a novel inducible mammalian galectin. Journal of Biological Chemistry 275 32106-32113.

Emond V, MacLaren LA, Kimmins S, Arosh JA, Fortier MA \& Lambert RD 2004 Expression of cyclooxygenase-2 and granulocyte-macrophage colony-stimulating factor in the endometrial epithelium of the cow is up-regulated during early pregnancy and in response to intrauterine infusions of interferon- $\tau$. Biology of Reproduction 70 54-64.

Farin CE, Imakawa K \& Roberts RM 1989 In situ localization of mRNA for the interferon, ovine trophoblast protein-1, during early embryonic development of the sheep. Molecular Endocrinology 3 1099-1107.

Farmer JL, Burghardt RC, Jousan FD, Hansen PJ, Bazer FW \& Spencer TE 2007 Galectin 15 (LGALS15) functions in trophectoderm migration and attachment. FASEB Journal [in press].

Flechon JE, Guillomot M, Charlier M, Flechon B \& Martal J 1986 Experimental studies on the elongation of the ewe blastocyst. Reproduction, Nutrition, Development 26 1017-1024.

Funston RN, Lipsey RJ, Geary TW \& Roberts AJ 2005 Effect of administration of human chorionic gonadotropin after artificial insemination on concentrations of progesterone and conception rates in beef heifers. Journal of Animal Science 83 1403-1405.

Garrett JE, Geisert RD, Zavy MT \& Morgan GL 1988a Evidence for maternal regulation of early conceptus growth and development in beef cattle. Journal of Reproduction and Fertility 84 437-446.

Garrett JE, Geisert RD, Zavy MT, Gries LK, Wettemann RP \& Buchanan DS $1988 b$ Effect of exogenous progesterone on prostaglandin F2 alpha release and the interestrous interval in the bovine. Prostaglandins 36 85-96.

Geisert RD, Renegar RH, Thatcher WW, Roberts RM \& Bazer FW 1982 Establishment of pregnancy in the pig: I. Interrelationships between preimplantation development of the pig blastocyst and uterine endometrial secretions. Biology of Reproduction 27 925-939.

Gertler A \& Djiane J 2002 Mechanism of ruminant placental lactogen action: molecular and in vivo studies. Molecular Genetics and Metabolism 75 189-201.

Gifford CA, Racicot K, Clark DS, Austin KJ, Hansen TR, Lucy MC, Davies CJ \& Ott TL 2007 Regulation of interferon-stimulated genes in peripheral blood leukocytes in pregnant and bred, nonpregnant dairy cows. Journal of Dairy Science 90 274-280.

Giudice LC \& Ferenczy A 1996 The endometrial cycle. In Reproductive Endocrinology, Surgery and Technology, pp 271-300. Eds EY Adashi, J Rock \& Z Rosenwaks. Philadelphia: Lippencott-Raven.

Golding MC, Long CR, Carmell MA, Hannon GJ \& Westhusin ME 2006 Suppression of prion protein in livestock by RNA interference. PNAS 103 5285-5290. 
Gray C, Bartol FF, Taylor KM, Wiley AA, Ramsey WS, Ott TL, Bazer FW \& Spencer TE 2000a Ovine uterine gland knock-out model: effects of gland ablation on the estrous cycle. Biology of Reproduction 62 448-456.

Gray CA, Taylor KM, Bazer FW \& Spencer TE $2000 b$ Mechanisms regulating norgestomet inhibition of endometrial gland morphogenesis in the neonatal ovine uterus. Molecular Reproduction and Development 57 67-78.

Gray CA, Bazer FW \& Spencer TE 2001a Effects of neonatal progestin exposure on female reproductive tract structure and function in the adult ewe. Biology of Reproduction 64 797-804.

Gray CA, Taylor KM, Ramsey WS, Hill JR, Bazer FW, Bartol FF \& Spencer TE $2001 \mathrm{~b}$ Endometrial glands are required for preimplantation conceptus elongation and survival. Biology of Reproduction 64 1608-1613.

Gray CA, Burghardt RC, Johnson GA, Bazer FW \& Spencer TE 2002 Evidence that absence of endometrial gland secretions in uterine gland knockout ewes compromises conceptus survival and elongation. Reproduction 124 289-300.

Gray CA, Adelson DL, Bazer FW, Burghardt RC, Meeusen EN \& Spencer TE 2004 Discovery and characterization of an epithelial-specific galectin in the endometrium that forms crystals in the trophectoderm. PNAS 101 7982-7987.

Gray CA, Abbey CA, Beremand PD, Choi Y, Farmer JL, Adelson DL, Thomas TL, Bazer FW \& Spencer TE 2006 Identification of endometrial genes regulated by early pregnancy, progesterone, and interferon tau in the ovine uterus. Biology of Reproduction 74 383-394.

Guillomot M 1995 Cellular interactions during implantation in domestic ruminants. Journal of Reproduction and Fertility 49 39-51.

Guillomot M, Michel C, Gaye P, Charlier N, Trojan J \& Martal J 1990 Cellular localization of an embryonic interferon, ovine trophoblastin and its mRNA in sheep embryos during early pregnancy. Biology of the Cell 68 205-211.

Guillomot M, Flechon JE \& Leroy F 1993 Blastocyst development and implantation. In Reproduction in Mammals and Man, pp 387-411. Eds C Thibault, MC Levasseur \& RHF Hunter. Paris: Ellipses.

Habermann FA, Wuensch A, Sinowatz F \& Wolf E 2007 Reporter genes for embryogenesis research in livestock species. Theriogenology 68 (Supplement 1) S116-S124.

Hannan NJ, Jones RL, White CA \& Salamonsen LA 2006 The chemokines, CX3CL1, CCL14, and CCL4, promote human trophoblast migration at the feto-maternal interface. Biology of Reproduction 74 896-904.

Hansen TR, Austin KJ, Perry DJ, Pru JK, Teixeira MG \& Johnson GA 1999 Mechanism of action of interferon- $\tau$ in the uterus during early pregnancy. Journal of Reproduction and Fertility 54 329-339.

Hasler JF, Henderson WB, Hurtgen PJ, Jin ZQ, McCauley AD, Mower SA, Neely B, Shuey LS, Stokes JE \& Trimmer SA 1995 Production, freezing and transfer of bovine IVF embryos and subsequent calving results. Theriogenology 43 141-152.

Hayashi K, Burghardt RC, Bazer FW \& Spencer TE 2007 WNTs in the ovine uterus: potential regulation of periimplantation ovine conceptus development. Endocrinology 148 3496-3506.

Hess AP, Hamilton AE, Talbi S, Dosiou C, Nyegaard M, Nayak N, Genbecev-Krtolica O, Mavrogianis P, Ferrer K, Kruessel J et al. 2007 Decidual stromal cell response to paracrine signals from the trophoblast: amplification of immune and angiogenic modulators. Biology of Reproduction 76 102-117.

Heyman Y, Camous S, Fevre J, Meziou W \& Martal J 1984 Maintenance of the corpus luteum after uterine transfer of trophoblastic vesicles to cyclic cows and ewes. Journal of Reproduction and Fertility 70 533-540.

Hofmann A, Zakhartchenko V, Weppert $M$, Sebald $H$, Wenigerkind $H$, Brem G, Wolf E \& Pfeifer A 2004 Generation of transgenic cattle by lentiviral gene transfer into oocytes. Biology of Reproduction 71 405-409.

Howard JM, Manzo R, Dalton JC, Frago F \& Ahmadzadeh A 2006 Conception rates and serum progesterone concentration in dairy cattle administered gonadotropin releasing hormone 5 days after artificial insemination. Animal Reproduction Science 95 224-233.

Imakawa K, Imai M, Sakai A, Suzuki M, Nagaoka K, Sakai S, Lee SR, Chang KT, Echternkamp SE \& Christenson RK 2006 Regulation of conceptus adhesion by endometrial CXC chemokines during the implantation period in sheep. Molecular Reproduction and Development 73 850-858.
Ing NH, Francis H, McDonnell JJ, Amann JF \& Roberts RM 1989 Progesterone induction of the uterine milk proteins: major secretory proteins of sheep endometrium. Biology of Reproduction 41 643-654.

Johnson KR, Ross RH \& Fourt DL 1958 Effect of progesterone administration on reproductive efficiency. Journal of Animal Science 17 386-390.

Johnson GA, Austin KJ, Collins AM, Murdoch WJ \& Hansen TR 1999a Endometrial ISG17 mRNA and a related mRNA are induced by interferon-tau and localized to glandular epithelial and stromal cells from pregnant cows. Endocrine 10 243-252.

Johnson GA, Spencer TE, Hansen TR, Austin KJ, Burghardt RC \& Bazer FW $1999 \mathrm{~b}$ Expression of the interferon tau inducible ubiquitin cross-reactive protein in the ovine uterus. Biology of Reproduction 61 312-318.

Johnson GA, Spencer TE, Burghardt RC, Joyce MM \& Bazer FW 2000a Interferon-tau and progesterone regulate ubiquitin cross-reactive protein expression in the ovine uterus. Biology of Reproduction 62 622-627.

Johnson GA, Spencer TE, Burghardt RC, Taylor KM, Gray CA \& Bazer FW $2000 \mathrm{~b}$ Progesterone modulation of osteopontin gene expression in the ovine uterus. Biology of Reproduction 62 1315-1321.

Johnson GA, Stewart MD, Gray CA, Choi Y, Burghardt RC, Yu-Lee LY, Bazer FW \& Spencer TE 2001 Effects of the estrous cycle, pregnancy, and interferon tau on $2^{\prime}, 5^{\prime}$ - oligoadenylate synthetase expression in the ovine uterus. Biology of Reproduction 64 1392-1399.

Kao LC, Tulac S, Lobo S, Imani B, Yang JP, Germeyer A, Osteen K, Taylor RN, Lessey BA \& Giudice LC 2002 Global gene profiling in human endometrium during the window of implantation. Endocrinology 143 2119-2138.

Kashiwagi A, Digirolamo CM, Kanda Y, Niikura Y, Esmon CT, Hansen TR, Shioda T \& Pru JK 2007 The postimplantation embryo differentially regulates endometrial gene expression and decidualization. Endocrinology 148 4173-4184.

Kazemi M, Amann JF, Keisler DH, Ing NH, Roberts RM, Morgan G \& Wooding FB 1990 A progesterone-modulated, low-molecular-weight protein from the uterus of the sheep is associated with crystalline inclusion bodies in uterine epithelium and embryonic trophectoderm. Biology of Reproduction 43 80-96.

Kile BT, Schulman BA, Alexander WS, Nicola NA, Martin HME \& Hilton DJ 2002 The SOCs box: a tale of destruction and degradation. Trends in Biochemical Sciences 27 235-241.

Kim S, Choi Y, Bazer FW \& Spencer TE 2003 Identification of genes in the ovine endometrium regulated by interferon tau independent of signal transducer and activator of transcription 1. Endocrinology 144 5203-5214.

Kleemann DO, Walker SK \& Seamark RF 1994 Enhanced fetal growth in sheep administered progesterone during the first three days of pregnancy. Journal of Reproduction and Fertility 102 411-417.

Klein C, Bauersachs S, Ulbrich SE, Einspanier R, Meyer HH, Schmidt SE, Reichenbach HD, Vermehren M, Sinowatz F, Blum H et al. 2006 Monozygotic twin model reveals novel embryo-induced transcriptome changes of bovine endometrium in the preattachment period. Biology of Reproduction 74 253-264.

Kwon H, Wu G, Bazer FW \& Spencer TE 2003a Developmental changes in polyamine levels and synthesis in the ovine conceptus. Biology of Reproduction 69 1626-1634.

Kwon H, Spencer TE, Bazer FW \& Wu G 2003 b Developmental changes of amino acids in ovine fetal fluids. Biology of Reproduction 68 1813-1820.

Larson SF, Butler WR \& Currie WB 1997 Reduced fertility associated with low progesterone postbreeding and increased milk urea nitrogen in lactating cows. Journal of Dairy Science $\mathbf{8 0}$ 1288-1295.

Larson SF, Butler WR \& Currie WB 2007 Pregnancy rates in lactating dairy cattle following supplementation of progesterone after artificial insemination. Animal Reproduction Science 102 172-179.

Lawson RA, Parr RA \& Cahill LP 1983 Evidence for maternal control of blastocyst growth after asynchronous transfer of embryos to the uterus of the ewe. Journal of Reproduction and Fertility 67 477-483.

Lea RG \& Sandra O 2007 Immunoendocrine aspects of endometrial function and implantation. Reproduction 134 389-404.

Lee RS, Wheeler TT \& Peterson AJ 1998 Large-format, two-dimensional polyacrylamide gel electrophoresis of ovine periimplantation uterine luminal fluid proteins: identification of aldose reductase, cytoplasmic actin, and transferrin as conceptus- synthesized proteins. Biology of Reproduction 59 743-752. 
Leese HJ 1995 Metabolic control during preimplantation mammalian development. Human Reproduction Update $163-72$.

Lewis SK, Farmer JL, Burghardt RC, Newton GR, Johnson GA, Adelson DL, Bazer FW \& Spencer TE 2007 Galectin 15 (LGALS15): a gene uniquely expressed in the uteri of sheep and goats that functions in trophoblast attachment. Biology of Reproduction 77 1027-1036.

Li Q, Zhang M, Kumar S, Zhu LJ, Chen D, Bagchi MK \& Bagchi IC 2001 Identification and implantation stage-specific expression of an interferon-alpha-regulated gene in human and rat endometrium. Endocrinology 142 2390-2400.

Maddox-Hyttell P, Gjorret JO, Vajta G, Alexopoulos NI, Lewis I, Trounson A, Viuff D, Laurincik J, Muller M, Tveden-Nyborg P et al. 2003 Morphological assessment of preimplantation embryo quality in cattle. Reproduction Supplement 61 103-116.

Mann GE \& Lamming GE 1999 The influence of progesterone during early pregnancy in cattle. Reproduction in Domestic Animals 34 269-274.

Mann GE \& Lamming GE 2001 Relationship between maternal endocrine environment, early embryo development and inhibition of the luteolytic mechanism in cows. Reproduction 121 175-180.

Mann GE, Lamming GE, Robinson RS \& Wathes DC 1999 The regulation of interferon-tau production and uterine hormone receptors during early pregnancy. Journal of Reproduction and Fertility 54 317-328.

Mann GE, Merson P, Fray MD \& Lamming GE 2001 Conception rate following progesterone supplementation after second insemination in dairy cows. Veterinary Journal 162 161-162.

Mann GE, Fray MD \& Lamming GE 2006 Effects of time of progesterone supplementation on embryo development and interferon-tau production in the cow. Veterinary Journal 171 500-503.

Martin PM \& Sutherland AE 2001 Exogenous amino acids regulate trophectoderm differentiation in the mouse blastocyst through an mTOR-dependent pathway. Developmental Biology 240 182-193.

Martin PM, Sutherland AE \& Van Winkle LJ 2003 Amino acid transport regulates blastocyst implantation. Biology of Reproduction 69 1101-1108.

Martin C, Pessemesse L, de la Llosa-Hermier MP, Martal J, Djiane J \& Charlier M 2004 Interferon- $\tau$ upregulates prolactin receptor mRNA in the ovine endometrium during the peri-implantation period. Reproduction 128 99-105.

Moffatt J, Bazer FW, Hansen PJ, Chun PW \& Roberts RM 1987 Purification, secretion and immunocytochemical localization of the uterine milk proteins, major progesterone-induced proteins in uterine secretions of the sheep. Biology of Reproduction 36 419-430.

Mohamed OA, Jonnaert M, Labelle-Dumais C, Kuroda K, Clarke HJ \& Dufort D 2005 Uterine $\mathrm{Wnt} / \beta$-catenin signaling is required for implantation. PNAS 102 8579-8584.

Moore K \& Thatcher WW 2006 Major advances associated with reproduction in dairy cattle. Journal of Dairy Science 89 1254-1266.

Nagaoka K, Nojima H, Watanabe F, Chang KT, Christenson RK, Sakai S \& Imakawa K 2003a Regulation of blastocyst migration, apposition, and initial adhesion by a chemokine, interferon gamma-inducible protein $10 \mathrm{kDa}$ (IP-10), during early gestation. Journal of Biological Chemistry 278 29048-29056.

Nagaoka K, Sakai A, Nojima H, Suda Y, Yokomizo Y, Imakawa K, Sakai S \& Christenson RK $2003 \mathrm{~b}$ A chemokine, interferon (IFN)-gamma-inducible protein $10 \mathrm{kDa}$, is stimulated by IFN-tau and recruits immune cells in the ovine endometrium. Biology of Reproduction 68 1413-1421.

Nakano H, Shimada A, Imai K, Takahashi T \& Hashizume K 2005 The cytoplasmic expression of E-cadherin and beta-catenin in bovine trophoblasts during binucleate cell differentiation. Placenta 26 393-401.

Nephew KP, McClure KE, Ott TL, Dubois DH, Bazer FW \& Pope WF 1991 Relationship between variation in conceptus development and differences in estrous cycle duration in ewes. Biology of Reproduction 44 536-539.

Niklaus AL \& Pollard JW 2006 Mining the mouse transcriptome of receptive endometrium reveals distinct molecular signatures for the luminal and glandular epithelium. Endocrinology 147 3375-3390.

Noel S, Herman A, Johnson GA, Gray CA, Stewart MD, Bazer FW, Gertler A \& Spencer TE 2003 Ovine placental lactogen specifically binds to endometrial glands of the ovine uterus. Biology of Reproduction $\mathbf{6 8}$ 772-780.

Pestka S 2007 The interferons: 50 years after their discovery, there is much more to learn. Biology of Reproduction 282 20047-20051.
Rempel LA, Francis BR, Austin KJ \& Hansen TR 2005 Isolation and sequence of an interferon- $\tau$-inducible, pregnancy- and bovine interferon-stimulated gene product 15 (ISG15)-specific, bovine ubiquitinactivating E1-like (UBE1L) enzyme. Biology of Reproduction 72 365-372.

Roberts RM, Liu L \& Alexenko A 1997 New and atypical families of type I interferons in mammals: comparative functions, structures, and evolutionary relationships. Progress in Nucleic Acid Research and Molecular Biology 56 287-325.

Robinson NA, Leslie KE \& Walton JS 1989 Effect of treatment with progesterone on pregnancy rate and plasma concentrations of progesterone in Holstein cows. Journal of Dairy Science 72 202-207.

Robinson RS, Mann GE, Lamming GE \& Wathes DC 2001 Expression of oxytocin, oestrogen and progesterone receptors in uterine biopsy samples throughout the oestrous cycle and early pregnancy in cows. Reproduction 122 965-979.

Rosenfeld CS, Han CS, Alexenko AP, Spencer TE \& Roberts RM 2002 Expression of interferon receptor subunits, IFNAR1 and IFNAR2, in the ovine uterus. Biology of Reproduction 67 847-853.

Salamonsen LA 1999 Role of proteases in implantation. Reviews of Reproduction 4 11-22.

Sandra O, Bataillon I, Roux P, Martal J, Charpigny G, Reinaud P, Bolifraud P, Germain G \& Al-Gubory KH 2005 Suppressor of cytokine signalling (SOCS) genes are expressed in the endometrium and regulated by conceptus signals during early pregnancy in the ewe. Journal of Molecular Endocrinology 34 637-644.

Satterfield MC, Bazer FW \& Spencer TE 2006 Progesterone regulation of preimplantation conceptus growth and galectin 15 (LGALS15) in the ovine uterus. Biology of Reproduction 75 289-296.

Satterfield MC, Dunlap KA, Hayashi K, Burghardt RC, Spencer TE, Bazer FW 2007 Tight and adherens junctions in the ovine uterus: differential regulation by pregnancy and progesterone, pp. en.2007-0321.

Schaiff WT, Barak Y \& Sadovsky Y 2006 The pleiotropic function of PPAR gamma in the placenta. Molecular and Cellular Endocrinology 249 10-15.

Schaiff WT, Knapp FF Jr, Barak Y, Biron-Shental T, Nelson DM \& Sadovsky Y 2007 Ligand-activated PPAR \{gamma\} alters placental morphology and placental fatty acid uptake in mice. Endocrinology 148 3625-3634.

Soares MJ 2004 The prolactin and growth hormone families: pregnancyspecific hormones/cytokines at the maternal-fetal interface. Reproductive Biology and Endocrinology 251.

Song G, Spencer TE \& Bazer FW 2005 Cathepsins in the ovine uterus: regulation by pregnancy, progesterone, and interferon tau. Endocrinology 146 4825-4833.

Song G, Spencer TE \& Bazer FW 2006a Progesterone and interferon-tau regulate cystatin $C$ in the endometrium. Endocrinology 147 3478-3483.

Song G, Bazer FW, Wagner GF \& Spencer TE $2006 b$ Stanniocalcin (STC) in the endometrial glands of the ovine uterus: regulation by progesterone and placental hormones. Biology of Reproduction 74 913-922.

Song G, Bazer FW \& Spencer TE 2007 Pregnancy and interferon tau regulate RSAD2 and IFIH1 expression in the ovine uterus. Reproduction 133 285-295.

Spencer TE \& Bazer FW 1995 Temporal and spatial alterations in uterine estrogen receptor and progesterone receptor gene expression during the estrous cycle and early pregnancy in the ewe. Biology of Reproduction 53 1527-1543

Spencer TE \& Bazer FW 2002 Biology of progesterone action during pregnancy recognition and maintenance of pregnancy. Frontiers in Bioscience 7 d1879-d1898.

Spencer TE \& Bazer FW 2004 Conceptus signals for establishment and maintenance of pregnancy. Reproductive Biology and Endocrinology 249.

Spencer TE, Becker WC, George P, Mirando MA, Ogle TF \& Bazer FW 1995 Ovine interferon-tau regulates expression of endometrial receptors for estrogen and oxytocin but not progesterone. Biology of Reproduction $\mathbf{5 3}$ 732-745.

Spencer TE, Stagg AG, Ott TL, Johnson GA, Ramsey WS \& Bazer FW 1999a Differential effects of intrauterine and subcutaneous administration of recombinant ovine interferon tau on the endometrium of cyclic ewes. Biology of Reproduction 61 464-470.

Spencer TE, Gray A, Johnson GA, Taylor KM, Gertler A, Gootwine E, Ott TL \& Bazer FW 1999b Effects of recombinant ovine interferon tau, placental lactogen, and growth hormone on the ovine uterus. Biology of Reproduction 61 1409-1418. 
Spencer TE, Stagg AG, Joyce MM, Jenster G, Wood CG, Bazer FW, Wiley AA \& Bartol FF 1999c Discovery and characterization of endometrial epithelial messenger ribonucleic acids using the ovine uterine gland knockout model. Endocrinology $1404070-4080$.

Spencer TE, Johnson GA, Burghardt RC \& Bazer FW 2004a Progesterone and placental hormone actions on the uterus: insights from domestic animals. Biology of Reproduction 71 2-10.

Spencer TE, Johnson GA, Bazer FW \& Burghardt RC $2004 b$ Implantation mechanisms: insights from the sheep. Reproduction 128 657-668.

Spencer TE, Johnson GA, Bazer FW \& Burghardt RC 2007a Fetal-maternal interactions during the establishment of pregnancy in ruminants. Society of Reproduction and Fertility 64 379-396.

Spencer TE, Johnson GA, Bazer FW, Burghardt RC \& Palmarini M 2007b Pregnancy recognition and conceptus implantation in domestic ruminants: roles of progesterone, interferons and endogenous retroviruses. Reproduction, Fertility, and Development 19 65-78.

Starbuck GR, Darwash AO \& Lamming GE 1999 The importance of progesterone during early pregnancy in the dairy cow. Cattle Practice 7 397-399.

Stark GR, Kerr IM, Williams BR, Silverman RH \& Schreiber RD 1998 How cells respond to interferons. Annual Review of Biochemistry 67 227-264.

Stewart MD, Johnson GA, Gray CA, Burghardt RC, Schuler LA, Joyce MM, Bazer FW \& Spencer TE 2000 Prolactin receptor and uterine milk protein expression in the ovine endometrium during the estrous cycle and pregnancy. Biology of Reproduction 62 1779-1789.

Thatcher WW, Hansen PJ, Gross TS, Helmer SD, Plante C \& Bazer FW 1989 Antiluteolytic effects of bovine trophoblast protein-1. Journal of Reproduction and Fertility 37 91-99.

Thatcher WW, Moreira F, Santos JE, Mattos RC, Lopes FL, Pancarci SM \& Risco CA 2001 Effects of hormonal treatments on reproductive performance and embryo production. Theriogenology 55 75-89.

Villa-Godoy A, Hughes TL, Emery RS, Chapin LT \& Fogwell RL 1988 Association between energy balance and luteal function in lactating dairy cows. Journal of Dairy Science 71 1063-1072.
Wathes DC \& Hamon M 1993 Localization of oestradiol, progesterone and oxytocin receptors in the uterus during the oestrous cycle and early pregnancy of the ewe. Journal of Endocrinology 138 479-492.

Whitley JC, Shulkes A, Salamonsen LA, Vogiagis D, Familari M \& Giraud AS 1998 Temporal expression and cellular localization of a gastrin-releasing peptide-related gene in ovine uterus during the oestrous cycle and pregnancy. Journal of Dairy Science 157 139-148.

Wiltbank JN, Hawk HW, Kidder HE, Black WG, Ulberg LC \& Casida LE 1956 Effect of progesterone therapy on embryo survival in cows of lowered fertility. Journal of Dairy Science 39 456-461.

Wooding FB 1982 The role of the binucleate cell in ruminant placental structure. Journal of Reproduction and Fertility 31 31-39.

Wooding FB 1984 Role of binucleate cells in fetomaternal cell fusion at implantation in the sheep. American Journal of Anatomy 170 233-250.

Wooding FB 1992 Current topic: the synepitheliochorial placenta of ruminants: binucleate cell fusions and hormone production. Placenta 13 101-113.

Wuensch A, Habermann FA, Kurosaka S, Klose R, Zakhartchenko V, Reichenbach HD, Sinowatz F, McLaughlin KJ \& Wolf E 2007 Quantitative monitoring of pluripotency gene activation after somatic cloning in cattle. Biology of Reproduction 76 983-991.

Yang RY \& Liu FT 2003 Galectins in cell growth and apoptosis. Cellular and Molecular Life Sciences 60 267-276.

Yankey SJ, Hicks BA, Carnahan KG, Assiri AM, Sinor SJ, Kodali K, Stellflug JN \& Ott TL 2001 Expression of the antiviral protein Mx in peripheral blood mononuclear cells of pregnant and bred, non-pregnant ewes. Journal of Endocrinology 170 R7-R11.

Received 17 July 2007

First decision 24 August 2007

Accepted 26 September 2007 